Rev. Marian Šuráb ${ }^{1}$

https://orcid.org/000-0003-4977-1386; Marian.Surab@frcth.uniba.sk

Comenius University in Bratislava

\title{
The Torment of Preaching and Listening in a Pluralistic Society
}

\begin{abstract}
The homily is an act of communication that consists of three elements: the preacher, the listener, and the homily. The purpose of homilies is to update the message of salvation and encourage the faithful to live the gospel. The homily as communication should take place in a peaceful environment. If this is not the case, preaching and listening may result in suffering. The paper mentions several reasons why this happens. The preacher may suffer from a new cultural and religious circumstance, authority issues, impaired spirituality, personal difficulties, loss of enthusiasm and fear or excessive stage fright. For listeners, the torment of listening may be caused by unfulfilled expectations, a bad relationship with the preacher, or homilies that lack simplicity, are full of abstract sentences, are long or unprepared.
\end{abstract}

Keywords: homily, preaching, suffering, laity

\section{Streszczenie}

Udręka głoszenia i słuchania w pluralistycznym społeczeństwie

Homilia jest aktem komunikacji, na który składają się trzy elementy: kaznodzieja, słuchacz i homilia. Celem homilii jest aktualizacja orędzia o zbawieniu i zachęcenie wiernych do życia według Ewangelii. Homilia jako akt komunikacji powinna odbywać się w spokojnej atmosferze. Jeśli tak nie jest, głoszenie i słuchanie może prowadzić do cierpienia. W artykule wymieniono kilka powodów, dla których tak się dzieje. Kaznodzieja może cierpieć z powodu nowych okoliczności kulturowych i religijnych, problemów z autorytetem, osłabionej duchowości, trudności osobistych, utraty

1 Rev. Marian Šuráb - Prof. ThDr., PhD. lectures on pastoral theology, homiletics and rhetoric at the Faculty of Roman Catholic Theology of Sts. Cyril and Methodius, Comenius University in Bratislava, at the Department of Practical Theology. He is a priest of the Nitra diocese. 
entuzjazmu i strachu lub nadmiernej tremy. Dla słuchaczy męka słuchania może być spowodowana niespełnionymi oczekiwaniami, złymi relacjami z kaznodzieją, homiliami, które nie są proste, są pełne abstrakcyjnych zdań, są długie lub nieprzygotowane.

Słowa kluczowe: homilia, przepowiadanie, cierpienie, świeccy

Recently, elements of neurology have been introduced into the theory of interpersonal communication. Experts say that cognitive processes such as thinking, speaking, and listening are physically strenuous activities. ${ }^{2}$ Pope Francis also refers to preaching and listening as stressful activities. In his exhortation Evangelii gaudium, he writes that lay people and priests alike often suffer because of homilies; "the laity from having to listen to them and the clergy from having to preach them. It is sad that this is the case." ${ }^{3}$ Finding the answer to why priests are tormented when they have to preach, and the faithful when they have to listen, is the aim of this paper.

\section{Preacher}

Human behaviour and activity are influenced by internal and external factors. Preaching is no exception. Homilies can be helped but also harmed by both external and internal factors. Harmful effects on preaching are manifested when the process of preaching turns into suffering and causes torment to preachers. There are several possible negative effects.

\subsection{New circumstances}

One of the phenomena that have an influence on preaching is the enormous increase in new circumstances that preachers have never faced in the past. Sociologist Gilles Lipovetsky writes that the world is ruled by a global culture that has caused a crisis of all the components that ensured stability in the past: religion, family, politics, relationships,

2 Cf. G. Carmine, Hovor ako TED, Brno 2016, p. 212-213.

3 Francis, Evangelii gaudium, p. 135. 
education, art, and other past standards are in disarray today. Now everything is seen from the perspective of market economy and competition. Humanities, including theology, are no longer attractive; sciences that support market and trade demands have taken over. The development of internet media allows everyone to enter the global village. People have two identities: one for the visible world and the other for the virtual world. The latter is gradually dominated by two great ideologies: ecology and political correctness. Man disappears, replaced by an abstract individual who is only defined by rights. Human rights are based on parliamentary consensus that denounces all borders and transcendental morality. Male and female identities are being redefined, no longer according to the principles of biology but based on personal decision. This general relativization is governed by the motto: all moral evaluation is forbidden. ${ }^{4}$

Religion is also undergoing great changes. Religious traditions are crumbling and everything that is sacred is becoming private. Matthew Fforde, a researcher in modern history, states that traditional religious denominations have entered a crisis and the ensuing vacuum in people's minds has been occupied by other forces. Institutions and practices that cater to people's spiritual needs have been rapidly growing. The emergence of obscure and often very dangerous sects, the superficial acceptance of Eastern religions, involvement in the occult, devotion to the New Age movement, interest in oracles, paranormal phenomena, astrology, psychoanalysis are tendencies the impact of which cannot be underestimated. They are also a sign of the decline of organized religion. ${ }^{5}$

That is why Pope Benedict XVI states:

It is difficult to proclaim God's word today in a world full of all kinds of sensations. The ministry of the word has become difficult. It can sometimes happen to a priest today that, as a prophet, Jeremiah rebels against his prophetic role. He would rather shake off the word that made him a weirdo and a fool. Well, the burden of the word must be borne... ${ }^{6}$

4 Cf. G. Lipovetsky, H. Juvin, Globalizovaný Západ, Praha 2012, p. 21-66.

Cf. M. Fforde, Desocializácia - Kríza postmoderny, Bratislava 2010, p. 179-180.

6 Benedict XVI - J. Ratzinger, Zasiahnutí neviditelným, Trnava 2006, p. 59. 
Today's preacher must therefore be fully aware that listeners live in a secular, pluralistic and media-governed society. One of the outcomes of this is that not all listeners of homilies are convinced that it is only religion, the gospel, or Christian values, that should shape their lives. Also, participation in Sunday Holy Mass and hearing the homily may be perceived by some as a mere contribution to the mosaic of their lives, which includes various types of experience, knowledge, and the search for alternatives. ${ }^{7}$ For many preachers, this situation can cause stress that has an impact on both the content and form of their preaching.

\subsection{Authority issues}

The bearer of authority has always been considered a man of seriousness, power, and influence. He was a personality respected by others. His authority was proof that he was able to influence the thinking and actions of others. The model of authority is Jesus Christ. Evangelist Matthew wrote, "And when Jesus finished these sayings, the crowds were astonished at his teaching, for he taught them as one who had authority, and not as their scribes" (Matt. 7:28-29). And evangelist Luke adds: "And all spoke well of him, and wondered at the gracious words which proceeded out of his mouth" (Luke 4:22). However, this passage ends with Jesus almost being thrown off a rock. In humans, admiration can quickly turn into dislike if authority directly interferes with their behaviour (Luke 4:23-30). Even today, this is one of the basic distinctions between preachers who have authority because they bear witness to what they are saying, and those who set safe maxims so that they do not come into conflict with listeners. ${ }^{8}$ In the Acts of the Apostles we read that "And as they were speaking to the people, the priests and the captain of the temple and the Sadducees came upon them, annoyed because they were teaching the people and proclaiming in Jesus the resurrection from the dead. And they arrested them and put them in custody until

7 Cf. T.F. Birkmann, Praktische Homiletik, Stuttgart 2000, p. 106-107.

Cf.Ch. Pope, To Teach as Jesus Taught - A Reflection on the Qualities of Jesus as Preacher and Teacher, https://blog.adw.org/2017/01/teach-jesus-taught-reflection-qualities-jesus-preacher-teacher (10.06.2020); H. Sławiński, Autorytet kaznodziei wsparciem autorytetu rodziców, in: Rodzina szkołą wartości, red. A. Pryba, Poznań 2011, p. 133-142 (Colloquia Disputationes, 18). 
the morrow, for it was already evening" (Acts 4:1-3). Even today, preachers must live with the fact that someone will constantly try to "arrest" them. This will happen when they proclaim God's plan for mankind and encourage life according to God's commandments and the principles of gospel. The subjectification of faith and religious life, the conviction of humans that they are the centre of the universe, their false sense of importance and untouchability, make preachers living targets for individuals, groups, and the media. If the preacher fails to cope with this, it can have a negative effect on his preaching.

\subsection{Impairment of spirituality}

Saint John Paul II in the exhortation Pastores dabo vobis writes that "the priest is above all a servant of the word of God, sanctified and sent to all to preach the gospel of the kingdom of God." This outlines the three main lines of preaching spirituality: openness to God's mystery, Christ's thinking, and love for the Church. ${ }^{9}$ If these are violated, the preacher's authenticity may be jeopardized.

A preacher who wants to proclaim the message of salvation to others must himself be open to it. ${ }^{10}$ Pope Benedict XVI addresses preachers like this: "The preacher should be the first to be addressed by the word of God, which he preaches, because, as St. Augustine says, there is no doubt barren who preaches the word of God on the outside and does not listen to it within." 11 Only this will allow him to reveal to the listeners the power of God's love, and make his words convincing. ${ }^{12}$ The preacher will be tormented by the homily if his life is not open to the mystery of God.

Pope Francis also mentions the temptations that may befall the preacher when listening to the Lord's words. The first one results in feelings of anxiety, disgust and closed mind. The second is thinking about what the passage will say to others, but not to the preacher himself. The third temptation is looking for excuses and diluting specific messages

9 Cf. John Paul II, Pastores dabo vobis, Trnava 1994, p. 26.

10 Cf. T. Lewandowski, Etos kaznodziei, in: Sługa Słowa, red. W. Przyczyna, Kraków 1997, p. 217-218.

11 Benedict XVI, Verbum Domini, Trnava 2011, p. 59.

12 Cf. Congregation for the Clergy, Direktórium o službe a živote kňazov, Trnava 1994, p. 45. 
of gospel passages. The fourth is the belief that God expects more from the preacher than he can fulfil. ${ }^{13}$

Preachers must live in a personal relationship with Christ. They must put Jesus Christ first, not themselves and their own views. Jesus is the protagonist of liturgy ${ }^{14}$ In the Letter to the Hebrews, it is written, "For the word of God is living and active, sharper than any two-edged sword, piercing to the division of soul and spirit, of joints and marrow, and discerning the thoughts and intentions of the heart" (Heb. 4:12). If the preacher is the first to be wounded by God's word, he can help others to hear and believe. Passing the sword of God's word is the most important step in preparing a homily. A personal relationship with Christ prevents the preacher from worrying about preaching the homily.

Preachers were sent by the Church. Mission is an essential element in preaching. It is a mandate for the preacher that his activity is not based on his power, but on the power of Jesus Christ and his Church. ${ }^{15}$ Neither the Church nor the preachers are absolute masters of the gospel to dispose of as they please. They must pass it on to others as ministers with complete fidelity. ${ }^{16}$ Thomas Brinkmann advises preachers to ask themselves the following questions: Do I see the Church as my employer, or a community of Jesus Christ, the wandering people of God? Am I a paid employee, or in the service of the Lord's magnificence? Do I preach for money and praise, or do I expect God's reward in the first place? Am I acting as a representative of the Church or as an employee of the Church? ${ }^{17}$ The Homiletic Directory quotes the words of St. Jerome, addressed to preachers: "Let not your deeds deny your words, lest while you preach in the church, someone would object, 'Why do you not do that?'... The words of Christ must be and think together."18

\footnotetext{
13 Cf. Francis, Evangelii gaudium, p. 153.

14 Cf. Benedict XVI, Sacramentum Caritatis, Trnava 2007, p. 23.

15 Cf. H. Simon, Kaznodzieja jako teolog, in: Stuga Słowa, red. W. Przyczyna, Kraków 1997,

16 Cf. Paul VI, Evangelii nuntiandi, Trnava 1999, p. 15.

17 Cf. T.F. Brinkmann, Praktische Homiletik, p. 31.

18 Congregation for Divine Worship and the Discipline of the Sacraments, Homiletické direktórium, Trnava 2017, p. 60.
} p. 131 . 
An actor, who has spent his life playing in Coca-Cola commercials, was asked how he liked the drink. He replied that he did not drink it at all because he did not like it. He only advertised it for money. ${ }^{19}$ It would be a tragedy if preachers performed their service only for money. Their preaching would turn into pretence and ultimately cause them to suffer.

\subsection{Loss of enthusiasm}

Priests engage in various pastoral activities to shape the Christian profile of their parishioners. A young priest felt the need to educate people in his parish in the knowledge of the Bible. He introduced this idea after Holy Mass to a group of parishioners and got unanimous feedback: "That's a great idea," they all said. In the evening, he informed the parish priest that people were very happy about the prospect of Bible study. The older and more experienced priest advised him to rephrase the question and ask them again. The next day, the young priest asked the same group, "Who would like to sign up for Bible study?" Only four hands were raised. The priest recognized that one thing was to agree, and another thing to actually participate. Such reactions can cause a preacher to suffer, as he fails to encourage listeners to not only speak but also to act. If the preacher spends longer time in one parish, he may get the feeling that no matter what he will say, people are still going to live as they please.

Modern parishes would not be able to function normally without the cooperation of priests - preachers and lay people. However, this cooperation is not always harmonious. Lay people of today are much more demanding and critical. Especially when they get to know the priest better. This can be similar to the story of the lion and the jackal. The jackal longed to befriend the lion. He saw that the lion was king, and that all the beasts feared him. One day the jackal came closer to the lion and asked him if he could be his friend. The lion was in a good mood and agreed. And so, the jackal became closer and closer to the lion every day. They began to walk together, and the jackal told the others how mighty and majestic the lion is. One day, as they walked hand in hand, the jackal could smell the lion's bad breath. He went to the other animals and

19 Cf. M. Klepetek, Komunikace, argumentace, rétorika, Praha 2008, p. 56-57. 
began to tell them that the lion stinks of rotten meat, is always asleep and doesn't wash himself. Suddenly, he only had words of criticism for the king. Priests - preachers may experience something similar with their parishioners. After the initial enthusiasm, people tend to sober out. Preachers should realise this and cope with it. If they fail, they will begin to suffer.

Preachers have various experiences with parishioners. However, they should always accept them as they are. Each of them is an independent person with his or her own value. They are not "preaching material," but, like the priests themselves, they are unique and irreplaceable human beings. In the homily, listeners must not be stigmatized and put down for being what they are. ${ }^{20}$ At the same time, each preacher must accept that there will be people at the church who are not very fond of him. They may simply dislike him; all he has to do is open his mouth and they are already uncomfortable. On the other hand, listeners who find themselves in everything that the preacher says, and suspect that he uses them as preaching material, can also be a problem. Others will visit the preacher and criticize some of his ideas. Finally, the preacher himself may dislike some parishioners. However, this should not cause the preacher to lose his passion for preaching of the gospel.

\subsection{Personal difficulties}

Thanks to Henry Nouwen, the term "wounded healer" is often mentioned in connection with the spiritual ministry of priests. The priest must be aware that he is not only a doctor but also a patient. His service will only be authentic if it springs from a heart wounded by suffering, because only so can the pastor truly experience the pains of the world. Accepting his injuries, he is offered the chance for transformation, from which a new life is born for him and for others. Nouwen knows that such a position is not easy for the priests of this world, where one of the main values is the strength of the individual who can handle everything. ${ }^{21}$

20 Cf. W. Engemann, Einführung in die Homiletik, Tübingen 2002, p. 396.

21 Cf. M. Dawlewicz, Duszpasterz jako terapeuta duchowy w ujęciu Henriego J. M. Nouwena, in: Boża terapia, red. R. Hajduk, Kraków 2005, p. 221-223. 
Timothy Radcliffe, a former Master of the Dominican order, adds that preachers should speak of God as they are, as vulnerable, misled, seeking, and doubtful human beings. ${ }^{22}$

Preaching has a public dimension. Preachers of today are under constant pressure to keep from failing. Nowadays people demand high quality service, and they also want high quality spiritual service and homily. Unfortunately, the preacher may not always be well and may not perform. It is even more difficult when a bad circumstance takes hold of him for a long time. He may experience feelings of resignation, depression, disappointment, and other difficulties. Preachers are part of today's generation, which is wounded. We have a generation of wounded lay people and some wounded priests. Stronger than in the past, the words of Jesus resonate with preachers themselves: "Come to me, all who labor and are heavy laden, and I will give you rest" (Matt. 11:28) and "Those who are well have no need of a physician, but those who are sick" (Matt. 9:12; Mark 2:17; Luke 5:31). In trying conditions, the strength of the preacher's personality is revealed. His weakness is also seen at the ambon. The faithful will quickly recognize that the preacher is struggling and needs help. This can be signalled by his opening words, facial expressions or gestures.

\subsection{Fear}

A certain level of stage fright is part of the basic equipment of all good speakers. At the same time, it is can also make or break the quality of any public performance. There are only two options: either it will help the performance or harm it. The preacher must want the fear to help him. If he can deal with it in a positive way, it will become a blessing for him. However, if fear takes hold of his whole being and begins to prevail, it may be destructive and even fatal. The preacher should realize that he is a personality who is there to lead others. It is not arrogance, but the reality and identity of preaching. He who speaks leads. He who preaches leads even more; he influences, directs, determines the attitudes of others by offering them models of life by the gospel. If the preacher does not

22 Cf. T. Radcliffe, Prečo chodit do kostola?, Zvolen 2013, p. 75. 
identify with his role, his fear could be detrimental to his performance. ${ }^{23}$ Severe anxiety may be associated with mental disorders, which require professional treatment.

Since ancient times, the story of a man has been told who was convicted in Rome because he had claimed to be able to talk to animals. They took him to the Circus maximus arena. The convict saw the bright crowds and felt the hot sand under his feet. The audience was looking forward to the performance. The moment finally arrives. The lion comes into the arena, gnawing its teeth and approaching the convict with a menacing roar. To the amazement of the spectators, however, the convict does not start running around the arena in panic but walks up to the lion. When they meet, the man whispers something in the lion's ear. Terrified, the lion rushes out of the arena. The emperor was so impressed by the scene that he set the convict free. He then asked him what he had whispered to the lion to make him run away. The man said, "It was easy. I simply told him he could eat me in peace, but that it was customary to give a speech after the feast. That's what the lion was terrified of." ${ }^{24}$ The story shows that public speaking is one of the greatest sources of fear.

\section{The faithful}

The main task of the homily is to encourage those present to actively live out the liturgical mystery. The homily should strengthen their faith, help them cope with the problems of life, and encourage them to serve as witnesses every day. Homilies are meant to help listeners glorify God, feel his presence in their lives, experience a community of love, and to reflect on their lives. The homily should be faithful to God and to man. ${ }^{25}$

What causes listeners to suffer while listening to homilies?

23 Cf. R.D. Wiedenmann, Der Rhetorik - Trainer, Wuppertal 1999, p. 82-91.

24 Cf. R. Braun, Umění rétoriky, Praha 2009, p. 168.

25 Cf. Komisja do spraw Życia i Posługi Kapłanów przy Krajowej Konferencji Biskupów Katolickich USA, „Dziś spełnity się słowa Pisma, któreście słyszeli”. Homilia w niedzielnym zgromadzeniu wiernych, przekł. H. Sławiński, Włoclawek 2002, p. 16-18. 


\subsection{Unfulfilled expectations}

Listeners' expectations from homilies are based on many circumstances and influences. The fulfilment of these expectations can cause them joy of listening, just as the lack of fulfilment can cause them to suffer while listening. The faithful come to liturgy expecting that the homily will be helpful and enriching. They carry with them many questions, doubts, problems, and difficulties. Everyone has personal issues that affect all areas of their life, from doubts in faith to interpersonal relationships. They expect that the homily will side with their current problems and will address their particular situation from the perspective of faith and relationship with God. ${ }^{26}$ They will appreciate if the preacher talks about their future perspectives and not just their difficulties. They want to be witnesses in the biblical sense to what they have personally experienced and tried. ${ }^{27}$ After all, their expectations are for the future. They hope that the homily will help them prepare for it. A good homily cannot linger in the present and not point out new perspectives that arise in the situation of individual listeners, however difficult. Listeners long for hope that will make their present life easier. Hope is closely linked to trust in God, which is what the listeners want the homily to convey. ${ }^{28}$

Pope Francis makes an important recommendation to preachers, "that we should not answer questions that no one is asking." ${ }^{29}$ The recommendation includes the Pope's experience, as well as the experience of many lay people, that preachers will sometimes talk about things that of no interest to anyone. This is possibly because some preachers live in their own world and, from their subjective point of view, preach homilies that do not appeal to listeners. Such a preacher may be trying, in good faith, to offer solutions that seem important to him, not realizing that they are unimportant to others. He should know that if he fails to address his listeners, they will travel in mind to other places. He must meet the

26 Cf. J. Kołodziejczyk, Religijność słuchaczy a ich oczekiwania wobec kazań, in: Stuga Słowa, red. W. Przyczyna, Kraków 1997, p. 220.

27 Cf. W. Engemann, Einführung in die Homiletik, p. 397.

28 Cf. K. Müller, Homiletik: ein Handbuch für kritische Zeiten, Regensburg 1994, p. 240-245.

29 Francis, Evangelii gaudium, p. 155. 
listeners in the environment in which they live. Only then can he answer their questions and meet their expectations. In the homily, the main thing is not to engage the listeners, but to understand their expectations.

\subsection{Bad relationship}

The homily will not be useful unless the preacher adopts a loving attitude that springs from God's love and manifests itself in empathy. The essence of God's love is mercy. Saint John Paul II wrote, "that Jesus proclaims the presence of God as the Father, love and mercy, he chose mercy as one of the main subjects of his teaching activity." 30 According to Pope Francis, God's mercy is close to the people when they perceive the Church as a good mother. That is why he calls on preachers to make their speech similar to that of a good mother. ${ }^{31}$ A homily speaks like a mother when it conveys how God and the Church care for each person. In a good homily, the man is represented in all dimensions of his human existence. Every listener should feel that the homily speaks primarily to him (mea res agitur). There must be an updated message that the story of God's mercy is fulfilled also in the lives of today's faithful. The preacher's human words are to channel the relief and joy that God brings through his Word and power. ${ }^{32}$ This process is helped by empathy, which has a deep religious dimension. It is based on God's behaviour; His empathy for man is embodied in the person of Jesus Christ. In the homily, empathy is manifested in the preacher's positive attitude to listeners. A negative relationship will have a depressing effect on those present..$^{33}$

The greatest suffering caused to the faithful is when the preacher gives up on them. This can be felt in the liturgical space. The preacher seems cold and the listeners are frozen with apathy. Preachers should never allow themselves to be influenced by bad experiences with parishioners. In any situation, they should not lose respect for themselves and

30 John Paul II, Rich in Mercy, Rome 1981, p. 3.

31 Francis, Evangelii gaudium, p. 39.

32 Cf. W. Kasper, Milosrdenstvo - Základný pojem evanjelia - kl’úč ku krestanskému životu, Trnava 2015, p. 194.

${ }_{33}$ Cf. M. Herbst, M. Schneider, ...wir predigen nicht uns selbst, Neukirchen-Vluyn 2001, p. 104. 
for the mission entrusted to them. The quality of their preaching sends a signal about how they are living their priesthood. The preacher, with his words and behaviour, should avoid putting listeners in a state of total resignation and torment. He must accept that he cannot understand or change everyone to match his ideas, or solve all problems. ${ }^{34}$

That is why Henryk Sławiński, a well-known Polish expert in homiletics, recommends the use of humour as a remedy against the torment of preaching and listening. He considers it important, however, that the preacher, the listeners, but also the preaching material itself are up to it. That is why humour must meet certain criteria in order to avoid being trivial. Above all, it must be related to the content of the homily itself and be respectful of the Scripture. It should also be fresh, respectful of those present and used with a sense of what is suitable. Humour helps to improve liturgical ambience. ${ }^{35}$

\subsection{Lack of simplicity and clarity}

Simplicity is the best design. The theory of communication encourages preachers to keep their thoughts simple and meaningful at the same time. The well-known Italian preacher Alessandro Pronzato ironically states that clarity of expression is becoming an increasingly rare feature in people who express themselves in speech and writing. As if clarity has become a sin of sorts. Pronzato quotes Cardinal Gianfranco Ravasi, who remarks: "Strange ambiguity, mysterious language, proclamations of superiority, and encrypted phrases often do not mean that the subject itself is difficult, but rather that the author - preacher is not completely clear, or even confused, about it. Operations of verbal terrorism no longer impress and are what they are: an empty society game or a deceptive veil behind which there is emptiness... When we hear just one of Jesus' sentences, it touches us: his words were not afraid to step into the dust of streets, to penetrate the passage of seasons, to be enriched by simple,

34 Cf. W. Enegemann, Einführung in die Homiletik, p. 396.

35 Cf. H. Sławiński, Kryteria i sposoby wykorzystania humoru w przepowiadaniu, Kryteria i sposoby wykorzystania humoru w przepowiadaniu, ,Ruch Biblijny i Liturgiczny” 70 (2017) nr 4, p. 293-308. 
transparent, and everyday images." Pronzato reminds preachers that being easy to understand is an act of love. Priests should realize that it is not a problem to show that they are educated, the problem is to make others understand them. If they want to speak clearly, they must not be confused in their minds. ${ }^{36}$ Slovak bishop Viliam Judák advises priests to speak in such a way that they are understood, and their preaching will touch everyone. He mentions the principle of St. Alfonso Liguori: "I must preach in such a way that even an illiterate worker can understand me." Simplicity is the opposite of arrogance and patronising. ${ }^{37}$

In homilies, we may also encounter a phenomenon called "the curse of knowledge." Someone who masters something very well does not take into account that others are not so familiar with the subject. The preacher may also find himself in this position. He thinks that what is clear to him is equally clear to his listeners. He should only use a certain portion of the available material so that the listeners can receive and process it. If the listeners do not understand the preacher, they will switch off and stop listening. Some will begin praying; others are thinking about their joys and sorrows, and others are simply suffering. ${ }^{38}$

The language of homily is associated with clarity and comprehensibility. If there is no word of God where there is no human word, then the preacher should use a language that will be understood by the listeners. God speaks clearly in the Scripture, and He wants to speak clearly through the mouths of preachers as well. It is an adaptation of God's word. Adaptation means preaching the revealed truth so that the listeners will understand it and decide to accept it into their lives. The preacher takes into account the spiritual environment of his listeners and seeks appropriate language so that they can receive the message of the gospel. This is similar to Jesus, who took into account the mentality of the people, their needs, as well as their cultural and religious environment. ${ }^{39}$

36 Cf. A. Pronzato, V ústrety človekovi, Trnava 2008, p. 92-98.

37 Cf. V. Judák, Kňazi dneška, Nitra 2017, p. 206.

38 Cf. Ch. Heath, D. Heath, Jak zaujmout hned na poprvé, Praha 2009, p. 26-32.

39 Cf. M. Šuráb, Aby nás radi počúvali, Nitra 2004, p. 98. 


\subsection{Abstract preaching}

People have been listening to stories since time immemorial. The story is considered a basic medium of interpersonal communication. Storytelling is captivating. Stories have a big impact on thinking and decision making. ${ }^{40}$ Jesus Christ teaches that stories that stem from human experience are the most effective. Therefore, shepherds, merchants, fishermen and soldiers in Judea liked to hear simple and comprehensible stories about people like themselves. ${ }^{41}$ The preacher should embrace narrative preaching. In the Bible, every time God is spoken of, the narrative method is used: God was in Egypt, in the burning bush, in the desert, in Jesus, through him He was present in the sick and in sinners. The biblical way of talking about God and Jesus' actions is such a narrative that the listener becomes part of the story and can identify with the individual characters. ${ }^{42}$ Theologian Wieslaw Pryczyna states that one of the advantages of narrative preaching is that it keeps homilies dynamic and helps keep the listeners' attention and suspense until the end. It engages a person totally, his reason, will and feelings. ${ }^{43}$ Narrative preaching uses stories, images, and examples. Pope Francis wrote to preachers that "a well-used image can help people enjoy the message we want to convey; it awakens desire in them and motivates the will in the spirit of the gospel." ${ }^{44}$

If the preacher spoke in lofty phrases, definitions, and abstract structures, he would not engage his listeners, but rather bother and bore them. Professor Jozef Vrablec, the founder of Slovak post-council homiletics, adds that Christianity is a narrative community. The proclamation of the gospel is not the communication of abstract truths, but the communication of God's saving actions, aided by the narration of specific stories. Jesus is not only the subject of theological research but first and foremost a person with whom one can experience faith. This experience

\footnotetext{
Cf. S. Lancaster, Na co lidé slyší, Praha 2016, p. 140.

Cf. J. Ehrenborg, J. Mattock, Přesvědčivé vystupovaní, Praha 1995, p. 46-49.

Cf. A. Schwarz, Jak pracovać nad kazaniem, Warszawa 1993, p. 93-95.

Cf. W. Pryczyna, Kaznodziejski przekaz opowiadań biblijnych, Kraków 2000, p. 141.

Francis, Evangelii gaudium, p. 157.
} 
is then presented, narrated as a personal testimony. ${ }^{45}$ Preaching in a narrative way is a sign that the preacher has matured. A homily told in a narrative way, which includes an image or example, will almost certainly not make listeners suffer.

\subsection{Long and unprepared homilies}

The length of the homily is a favourite subject of homiletics experts, preachers and lay people alike. It can be discussed from various perspectives. Many lay people criticize priests for long preaching. They say that in addition to the sacrifice of bread and wine, they also offer the sacrifice of listening. In fact, the Catholic preaching tradition does not really remember short sermons or homilies. Quite the opposite. Timothy Radcliffe OP points out that in the Acts of the Apostles, we read how St. Paul preached a very long sermon in Troas. A young man named Eutychus was sitting in a third-floor window and listening. After a while, however, he fell asleep, fell out of the window and died. Paul came to him, embraced him, and the boy came to life (cf. Acts 20:7-12). Radcliffe adds that in this event, preachers may find some solace: at least there was no life lost during their own long homilies. ${ }^{46}$ Canadian episcopal vicar for parish renewal James Mallon writes from personal experience that preachers should not apologize for longer sermons. Preaching is essential and must be taken seriously. It is not enough to just offer listeners "God's appetizers." The homily should not be spiritual fast food. Perhaps homilies would not be as much a test of what people will endure if the preacher focused on the style and content of his preaching. ${ }^{47}$

The issue of length is closely linked to the question of preparation. It is often the case that those who make little effort to prepare their homilies find it hard to finish preaching them. A ready preacher is like a good pilot: he knows when to land. We'd rather have listeners tell each other, "we could keep listening to him," than have them glancing at their

45 Cf. J. Vrablec, A. Fabian, Homiletika I. - II. základná a materiálna, Trnava 2001, p. 58-59.

${ }^{46}$ Cf. T. Radcliffe, Sakramentálnost' slova, http://dominikani.sk/wp-content/uploads/2016/08/Radcliffe-Sakrament\%C3\%A1lnos\%C5\%A5-slova.pdf (4.10.2020).

47 Cf. J. Mallon, Proměna farnosti, Praha 2018, p. 122-123. 
watches and putting them against their ears to check if they had stopped. Good speakers have one principle: What I don't say will help what I do say. Limited time brings out the preacher's creativity. The less time he has at his disposal, the better he can use it. ${ }^{48}$ Bishop Judák adds that the prominent sign of "homiletic abuse" is the long and monotonous homily. ${ }^{49}$ Perhaps the most beautiful thought of the Holy Father Francis to preachers is "that the word of the preacher should not take up much space and the Lord may shine more than his servant." 50

\section{Conclusion}

To prepare for the beatification of St. John Paul II, experts studying his life came up with a catalogue of qualities that show why he became a world authority at the turn of the millennium. These qualities are inspirational for every preacher. They can help preachers so that their ministry will not be a source of suffering, just as listening to them will not be a source of suffering to their listeners:

1. A lasting awareness of God's presence that results in love of neighbour.

2. Fascination with the secrets of human beings. Exploring the ways they mature in love, and striving for their salvation.

3. Sense of justice and sensitivity to the needs of people, especially those who endure social wrongdoings and are at risk of harm (the unborn, the poor, the youth, the sick).

4. Openness to dialogue with each person, but equally determination to defend the unrestrained truth.

5. espect for the diversity of vocations in the Church and the promotion of cooperation between clergy and laity.

6. Trinitarian piety, complemented by Marian veneration.

7. Sincere love for the Church.

8. Intense diligence.

48 Cf. G. Carmine, Hovor ako TED, p. 229.

49 Cf. V. Judák, Kňazi dneška, p. 206.

50 Francis, Evangelii gaudium, p. 138. 
9. Intellectual honesty in answering each question.

10. High standards of speaking and writing. ${ }^{51}$

The homily is supposed to cause only one type of suffering. This happens when the faithful decide to change their lives upon hearing it. This is not an easy process and it goes along with suffering. On the other hand, if the process of speaking and listening is accompanied by suffering, it will not bring metanoia, it will cause resignation instead. Preaching would lose its meaning if it caused resignation. It serves its purpose when the listeners, just like those who came to John the Baptist, ask the preacher after he finishes his sermon: "What then shall we do?" (Luke 3:10).

\section{References}

Benedict XVI/J. Ratzinger, Zasiahnutí neviditel'ným, Trnava 2006.

Benedict XVI, Sacramentum Caritatis, Trnava 2007.

Birkmann T.F., Praktische Homiletik, Stuttgart 2000.

Braun R., Umění rétoriky, Praha 2009.

Carmine G., Hovor ako TED, Brno 2016.

Congregation for the Clergy, Direktórium o službe a živote kňazov, Trnava 1994.

Dawlewicz M., Duszpasterz jako terapeuta duchowy w ujęciu Henriego J.M. Nouwena, in: Boża terapia, red. R. Hajduk, Kraków 2005.

Ehrenborg J., Mattock J., Přesvědčivé vystupovaní, Praha 1995.

Engemann W., Einführung in die Homiletik, Tübingen 2002.

Fforde M., Desocializácia - Kríza postmoderny, Bratislava 2010.

Francis, Evangelii gaudium, Trnava 2014.

Heath Ch., Heath D., Jak zaujmout hned na poprvé, Praha 2009.

Herbst M., Schneider M., ...wir predigen nicht uns selbst, Neukirchen-Vluyn 2001.

John Paul II, Pastores dabo vobis, Trnava 1994.

John Paul II, Rich in Mercy, Rome 1981.

Judák V., Kňazi dneška, Nitra 2017.

Kasper W., Milosrdenstvo - Základný pojem evanjelia - kl'úč ku krestanskému životu, Trnava 2015.

Klepetek M., Komunikace, argumentace, rétorika, Praha 2008.

Kołodziejczyk J., Religijność słuchaczy a ich oczekiwania wobec kazan, in: Sługa Słowa, red. W. Przyczyna, Kraków 1997. p. 25.

P.P. Maturkanič, Pápežskénávstěvy České republiky a jejich pastorační význam, Praha 2018, 
Komisja do spraw Życia i Posługi Kapłanów przy Krajowej Konferencji Biskupów Katolickich USA, „Dziś spetnity się stowa Pisma, któreście słyszeli”. Homilia w niedzielnym zgromadzeniu wiernych, przekł. H. Sławiński, Włocławek 2002 (Ancilla Verbi, 2).

Lancaster S., Na co lidé slyší, Praha 2016.

Lewandowski T., Etos kaznodziei, in: Stuga Słowa, red. W. Przyczyna, Kraków 1997. Lipovetsky G., Juvin H., Globalizovaný Západ, Praha 2012.

Mallon J., Proměna farnosti, Praha 2018.

Maturkanič P.P., Pápežské návstěvy České republiky a jej ich pastorační význam, Praha 2018.

Müller K., Homiletik: ein Handbuch für kritische Zeiten, Regensburg 1994.

Paul VI, Exhortácia Evangelii nuntiandi, Trnava 1999.

Pope Ch., To Teach as Jesus Taught - A Reflection on the Qualities of Jesus as Preacher and Teacher, https://blog.adw.org/2017/01/teach-jesus-taught-reflection-qualities-jesus-preacher-teacher (10.06.2020).

Pronzato A., V ústrety človekovi, Trnava 2008.

Przyczyna W., Kaznodziejski przekaz opowiadań biblijnych, Kraków 2000.

Radcliffe T., Prečo chodit do kostola?, Zvolen 2013.

Schwarz A., Jak pracovać nad kazaniem, Warszawa 1993.

Simon H., Kaznodzieja jako teolog, in: Sługa Słowa, red. W. Przyczyna, Kraków 1997.

Sławiński H., Autorytet kaznodziei wsparciem autorytetu rodziców. Rodzina szkoła wartości, red. A. Pryba, Poznań 2011, s. 133-142 (Colloquia Disputationes, 18).

Sławiński H., Kryteria i sposoby wykorzystania humoru w przepowiadaniu, „Ruch Biblijny i Liturgiczny" 70 (2017) nr 4, p. 293-308.

Šuráb M., Aby nás radi počúvali, Nitra 2004.

The Holy Bible: Revised Standard Version, Oxford 2006.

Vrablec J., Fabian A., Homiletika I. - II. základná a materiálna, Trnava 2001.

Wiedenmann R.D., Der Rhetorik - Trainer, Wuppertal 1999. 